\title{
PUBLIC HEALTH EXPERIENCES FROM INTERWAR CROATIA (YUGOSLAVIA) AND MAKING WESTERN MEDICINE IN THE 1930s CHINA
}

\section{JAVNOZDRAVSTVENA ISKUSTVA IZ MEĐURATNE HRVATSKE (JUGOSLAVIJE) I STVARANJE ZAPADNE MEDICINE U KINI 1930-ih}

\section{Željko Dugac*}

\begin{abstract}
SUMMARY
To gain control and domination over a particular territory, medicine was often used as a tool for promoting different interests. Using the activities of the League of Nations Health Organization and the Rockefeller Foundation on the territory of China in I930s, this paper analyses the interconnection of the international and local factors in the transformation of the traditional Chinese milieu to suit the new and trendy public health projects. These activities were conducted not only to improve the public health conditions in the country, but also to introduce the Chinese public health to the processes of internationalization and standardization to the west oriented type of medicine and medical education. Initiated processes necessarily interfered with the political influences, economical interests and cultural environment as well as with military actions in this very turbulent time of Chinese history. Public health activities were carried out by the group of international experts. Among them the main position took two Croatian physicians: Andrija Štampar (one of the founders of the World Health Organisation later) and Berislav Borčić (a director of the School of Public Health in Zagreb). On the basis of correspondence between these two physicians, as well as
\end{abstract}

Correspondence address: Željko Dugac, Croatian Academy of Arts and Sciences, Divison for the History and Philosophy of Science, Department of Philosophy of Science, Ante Kovačića 5, Zagreb, Croatia.E-mail: dugac@hazu.hr. 
the travel diary of Andrija Štampar, this essay presents some less known details about the situation in China and the interlacing between politics and medicine.

Keywords: history of public health, history of medicine, interwar China, Andrija Štampar, Berislav Borčić

\section{INTRODUCTION $^{1}$}

The promotion of political and economic interests, as well as cultural and scientific unification, was often expressed through medicine and especially public health. Interwar period presents an excellent opportunity to study this phenomenon. With the establishment of the League of Nations and its Health Organization (LNHO), health and, especially, public health issues attained international-indeed, global-importance. Public health problems, as defined by the scientific Western medicine, expanded out of the boundaries of Europe and Northern America to spread worldwide and to attempt to unify other health systems into its idiosyncratic format. ${ }^{2}$

This essay discusses experiences of two Croats from the Kingdom of Serbs, Croats and Slovenes (from I929 Kingdom of Yugoslavia), Dr Berislav Borčić (I89I-1977) and Dr Andrija Štampar (I888-1958), ${ }^{3}$ who had the leading roles among international public health experts working in the I930s China towards the introduction of Western standards of public health and medicine. Berislav Borčić was charged with organizing a central hygiene

1 This work was created within the research project of the Croatian Science Foundation: The Transition of Croatian Elites from the Habsburg Monarchy to the Yugoslav State, led by Prof. dr. sc. Iskra Iveljić.

2 See more in: Weindling P, ur. International organisations and movements 1918-1939. Cambridge: Cambridge University Press; 1995.; Gross Solomon S, Murard L, Zylberman P. Shifting Boundaries of Public Health: Europe in the Twentieth Century. New York: University of Rochester Press; 2008.; Borowy I, Gruner W. (eds.). Facing Illnesses in Troubled Times: Health in Europe in the Interwar Years. Frankfurt am Main: Peter Lang; 2005.; Weindling P. Philanthropy and World Healh: The Rockefeller Foundation and the League of Nations Health Organisation. Minerva 1997.; Farley J. To Cast out Disease. A History of the International Health Division of the Rockefeller Foundation (1913-1951). Oxford, New York: Oxford University Press; 2004.; Borowy I. Coming to Terms With World Health: The League of Nations Health Organisation 1921-1946, Frankfurt am Main, Peter Lang, 2009.

3 On Andrija Štampar as one of the most prominent public health experts of the twentieth century and a creator of the WHO, see more in: Dugac Ž. Andrija Štampar (1888-1958): Resolute Fighter for Health and Social Justice. In: Borowy I., Hardy A. (ed.), Of Medicine and Men: Biographies and Ideas in European Social Medicine between the World Wars, Frankfurt am Main, Peter Lang, 2008; Grmek M. D. U borbi za narodno zdravlje, Izabrani članci Andrije Štampara, Zagreb, ŠNZ Andrija Štampar, 1966.

About Berlsilav Borčić in: Belicza B, Rastija M. Prilog poznavanju života i rada dra Berislava Borčića (1891-1977), eksperta Lige Naroda i Svjetske zdravstvene organizacije. Saopćenja 30, 1984, 129-144. 
institute in the Chinese capital, Nanking (Nanjing), while Andrija Štampar was appointed counsellor to the Chinese president Chiang Kai-shek. They came to China with the experience of having had set up broadly ranging public health projects on the territory of today's Croatia, as well as the whole of the Kingdom of Serbs, Croats and Slovenes. Mentioned Kingdom was an agricultural country with an unevenly, mostly poorly, developed public health system. Štampar, a head of department in the Ministry of Public Health, and Borčić

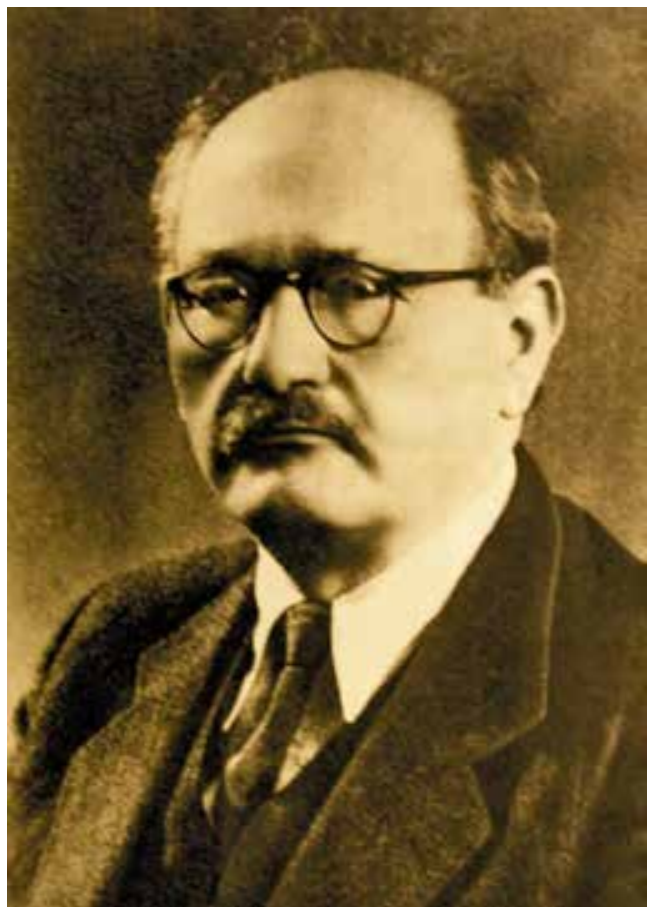

Prof. dr. Andrija Štampar (1888-1958) as the director of the School of Public Health, had conducted large campaigns to establish public health institutions, educational programmes for the public health staff, as well as comprehensive systems of permanent and organized popular health education targeted at nearly all social and age groups, in urban and in rural communities. Additionally, Štampar and Borčić were instrumental in advancing international collaboration in the training of the medical staff: along with the specialized education in the newly founded social-medical institutions, it also included study trips overseas. Studying in international centres, Yugoslav medical staff gained new knowledge and exchanged ideas and experiences. Štampar, Borčić and their collaborators focused on increasing access to medical services; securing hygiene infrastructure, organizing energetic anti-epidemic campaigns as well as conducting continuous health education and working to improve economic factors affecting the health of the population. Their activities influenced vital indicators as well as increased hygiene and health conditions as well as the general culture and education of the population. The comprehensive project to improve the public health of the country did not remain without notice. Experts from the League of Nations Health Organization as well as the Rockefeller Foundation praised 
this innovative work, and especially the Rockefeller Foundation financially supported Yugoslav efforts. Croatia and the whole of the Kingdom became popular destinations for public health study trips. ${ }^{4}$ The case of a rural, underdeveloped country that within a short period of time managed to significantly improve its public health became a model for similar activities in comparable countries. China was the first one to try it. ${ }^{5}$

Interwar time was a turbulent period in Chinese history: the time of dramatic ideological, military and political conflict as well as external threat followed by the Japanese occupation. It was the time when this large country, troubled by its lack of unity, war, conflicts of ideas and interests, tried to take part in a project that, in many ways, was new and alien: Western medicine. ${ }^{6}$

Scholars of the rig2os and I930s public health history, the era of Chiang Kai-shek's government in China, and especially Iris Borowy emphasize that it was the LNHO that pioneered the first involvement of Western medicine in China, and that it arrived at the direct Chinese invitation. Earlier entrances of Western medicine into China were through missionaries, who established their hospitals, or through private practitioners who in most cases came to practice in treaty ports or other regions in which Europeans and Americans resided. Whether Western medicine arrived in China invited or not is not the topic of this essay. Yet it is important to stress that public health and medical elements that arose within the West came to China in a legitimate manner and at the invitation of highest governmental ranks, to form local health systems on the Western model. China thus began to build a Western health system. Of course, building of this system could not take place overnight and without the participation of locals educated at medical schools that followed the principles of Western medicine. Many Chinese had attended European and American medical schools as well as

4 Prausnitz C. The Theaching of Preventive Medicine in Europe. London: Oxford University Press; 1933, 121-40, 169.; Chen C.C. Medicine in Rural China. Berkley: University of California Press, 1989.; Dugac Ž. Like yeast in fermentation: public health in interwar Yugoslavia, In: Promitzer C., Trubeta S., Turda M. (eds.), Hygiene, Health and Eugenics in Southeastern Europe to 1945, Budapest, New York, CEU Press, 2010, 193-232.

5 After the Second World War, countries (mainly former European colonies) that came together in the Non-alignment movement drew on Croatian/Yugoslav experiences to build their own public health systems.

6 For more on health and Chinese medicine in this period, see: Hiller S.M, Jewell J.A. Health Care and Traditional Medicine in China 1800-1982, London, Routledge, 1983; Yip K. Health and National Reconstruction in Nationalist China, Michigan, Association for Asian Studies, 1995. An interesting book of potential interest to the readers of this essay, on the history of public health in China between the 1930s and the end of the twentieth century, was recently published: Borowy I. (ed.), Uneasy Encounters: The Politics of Medicine and Health in China 1900-1937, Frankfurt am Main, Peter Lang, 2009. 
postgraduate and professional educational courses. With the establishment of the collaboration with the LNHO, such educational and training opportunities multiplied?

When in 1930 the LNHO charged the Danish professor Knud Faber with a study of medical education in China, it came to their knowledge that China had no more than three medical schools that could, to some extent, satisfy Western standards. These included the Sun Yat-sen University Medical School in Canton (Guanzhou), the Central University Medical College in Shanghai, and the Peking Union Medical College. ${ }^{8}$ Yet only the latter, established with the Rockefeller foundation funds, met Western standards. ${ }^{9}$ In the same report Faber stated that in China there are no more than 700 hospitals, the bulk of which were small and inadequately equipped, besides being outside control of either central or local national authorities, and no more than 5000 doctors $^{10}$ trained in the theory and practice of scientific medicine. ${ }^{11}$

7 Numerous Chinese health administrative employers specialized abroad. Dr Tsai-Hong, in charge of Division of Quarantine and Epidemiology in the National Health Department of China, studied health practices in several European countries and the USA. He also investigated the modern application of epidemiology in the Kingdom of Yugoslavia. Dr. L. C. Yen, chef of the Division of Medical Administration in the Central Health Department studied public health administration and licensing of doctors and midwives, also in Yugoslavia. Dr. P. Z. King studied the organisation and work of several institutes of hygiene in Europe, among them in Yugoslavia that had the similar role as the Central Field Health Station in Nanking (Nanjing), the direction of which he was supposed to take over. Dr. Chen Wan Li, health commissioner of the Province of Chekiang (abolished after 1955) studied general public health work, as well as sanitary and medical institutions, in Yugoslavia and in some other European countries (Annual Report of the Health Organisation for 1930, p. 22. Archives of the LNHO, Geneva).

8 Minutes of the Seventeenth Session of the Health Committee, 4-8 May 1931, Annex 7, Note by the Medical Director on the Report on Medical Schools in China, prepared by Professor Knud Faber, Archives of the LNHO, Geneva. Faber K. Report on medical schools in China. Geneva, League of Nations Health Organisation, 1931.

9 For more on this important feat of the Rockefeller Foundation, see: Brown Bullock, M., An American Transplant: The Rockefeller Foundation and Peking Union Medical College, University of California Press, Berkeley, 1989; Litsios S. Selskar Gunn and China: The Rockefeller Foundation's 'Other' Approach to Public Health, Bulletin of the History of Medicine, 79: 295-318, 2005; Litsios S. The Rockefeller Foundation's Struggle to Correlate Its Existing Medical Program with Public Health Work in China; In: Borowy I. (ed.), Uneasy Encounters: The Politics of Medicine and Health in China 1900-1937, Frankfurt am Main, Peter Lang, 2009, 177-203.

10 As a comparison, in the tiny Banovina Hrvatska (Province of Croatia) of the underdeveloped Kingdom of Yugoslavia, with its just over 4 million inhabitants, there were around 1700 physicians in the 1930s.

11 Minutes of the Seventeenth Session of the Health Committee, 4-8.5.1931, Annex 7, Note by the Medical Director on the Report on Medical Schools in China, prepared by Professor Knud Faber, Archives of the LNHO, Geneva. 
Together with the LNHO, the contemporary Chinese government launched a daring project to create a new health system that would allow the education of physicians, establishment of institutions (including laboratories) and organizing the administration, the task of which was to prepare and monitor health regulations. Such a comprehensive health system was a novelty. Scholars, such as AnElissa, Borowy, Brown Bullock, Litsios and Yip, have written extensively about the establishment of the system, ministry, legislation, schools, problems and successes. ${ }^{12}$ Probably because of linguistic barriers, inadequate state of research of archival documents dating from the Kingdom of Serbs, Croats and Slovenes, and the long inaccessibility of Andrija Štampar's diaries, researchers paid little attention to the impact that these two public health experts had on international public health. Similarly, the innovative model of public health developed in Croatia and in the Kingdom of Serbs, Croats and Slovenes/Yugoslavia between the wars, while mentioned in the literature, was not adequately assessed and its import for both interwar and postwar international health analysed. For this reason, this model was never placed in a broader context of modern public health history, and while the two protagonists remained little known to the international scholarly community. ${ }^{13}$

This essay uses archival documents kept in the Croatian State Archives in Zagreb and the Archives of the LNHO in Geneva to illuminate certain hitherto little explored details of this comprehensive project of the Nationalist China, supported by the international community. It focuses on the work of two key experts whose role was to put the League of Nations Chinese plans into action: Berislav Borčić and Andrija Štampar. An especially valuable source is Andrija Štampar's diary written during his travels in China. ${ }^{14}$ These two Croatian physicians, in their capacity as the LNHO experts and consultants to the Chinese government, took key roles in the reform of the health system in China. They worked in areas of high priority

12 AnElissa L. Chinese Medical Modernization: Comparative policy continuities, 1930s-1980s, New York, Praeger, 1982; Borowy I. Thinking Big-League of Nations Efforts towards a Reformed National Health System in China. In: Borowy I. (ed.), Uneasy Encounters: The Politics of Medicine and Health in China 1900-1937, Frankfurt am Main, Peter Lang, 2009, 205-228.

13 Comp: Dugac Ž. Like yeast in fermentation: public health in interwar Yugoslavia, In: Promitzer C., Trubeta S., Turda M. (eds.), Hygiene, Health and Eugenics in Southeastern Europe to 1945, Budapest, New York, CEU Press, 2010, 193-232.

14 The original diary of Andrija Štampar is kept in the Croatian State Archives in Zagreb. It covers the time period of Štampar's international career between 1931 and 1938. The diary was published in Croatian almost in its entirety and accompanied with an introduction and notes. See: Dugac Ž, Pećina M. (eds.) Andrija Štampar: dnevnik s putovanja 1931-1938, Zagreb, HAZU, Srednja Europa - ŠNZ Andrija Štampar, 2008. 
such as protection from contagious diseases, immunization campaigns, establishment of bacteriological and other laboratories as well as a network of health and preventative institutions. They also promoted further development of modern health education and quarantine services in maritime transport. The latter area was of particular importance because the League's experts observed that the maritime quarantine and sanitary supervision in Chinese ports were ineffective and so presented a potential threat not only to China and Far East ${ }^{15}$, but also to the European and American ports. The medical director of the Health Organisation of League of Nations, Polish bacteriologist Ludwik Rajchman, focused on these problems as early as his first visits to China. ${ }^{16}$

In China, Borčić and Štampar followed prescriptions issued by Rajchman and complemented the work of Selskar Gunn who represented the Rockefeller Foundation in the country. It is interesting to observe that it was precisely the group that had produced excellent results in the Kingdom of Serbs, Croats and Slovenes in the I920s that gathered in China to work on the same problems in the r93os. The group comprised not just Štampar and Borčić but also Gunn, who at the time was the Rockefeller Foundation's representative in the Kingdom and who decided on all projects that took place in the country. Gunn had shown remarkable sensitivity to local needs, understanding of the political situation and enviable diplomatic skills. ${ }^{17}$ Štampar's ideas, experience and power, as well as Borčić's exper-

15 Far East as a term was popularized during the period of the British Empire for lands east of British India. Far East in its usual sense is comparable to East and Southeast Asia as well as Russian Far East might be included in the Far East to some extent.

16 Rajchman's early critiques of the maritime quarantine may be found in: Borowy I. Thinking big: League of Nations efforts towards a reformed national health system in China. In: Borowy I. (ed.), Uneasy Encounters: The Politics of Medicine and Health in China 1900-1937, Frankfurt am Main, Peter Lang, 2009, 205-228.

17 In his diary, Štampar referred to Gun as 'our old friend Gunn'. Štampar furthermore wrote: 'When Gunn was appointed to the position of the Foundation's vice-president for Far East, he wrote to me several times. At that time we had not thought we would meet again at this end of the world and when we saw each other again we remembered our memories from Yugoslavia and the times when we travelled together and made plans. If it weren't for Gunn, who knows if the Foundation would have taken so much interest in our work, and if it would have helped us so much. In the past few months, Gunn visited a large proportion of Chinese institutions, and it is especially useful that, with the help of an expert, he examined the current state of all higher education institutions in China. The results of this study were dismal; the number of institutions that may be treated as 'higher education' is incredibly small and most of them are in poor condition, inadequately equipped to teach curricula with which they are charged. At the same time, the study examined missionary institutions and they were shown to be no better' (Dugac Ž, Pećina M. (eds.) Andrija Štampar: Dnevnik s putovanja 1931-1938, Zagreb, HAZU, Srednja Europa, ŠNZ Andrija Štampar, 2008). For more on the projects of the Rockefeller Foundation in 
tise and tenacity, formed the foundations of Rajchman's plans for China. It was a dream team: Borčić and Štampar ${ }^{18}$ for the League and Gunn for the Rockefeller Foundation: a line-up that produced a miracle in the Kingdom of the Serbs, Croats and Slovenes that awed the entire international community in the I920s. It all seemed ideal: all they had to do was to apply experiences collected while working in a small, underdeveloped, largely rural country, to a large, underdeveloped, largely rural country. Yet problems appeared.

\section{Andrija Štampar and Berislav Borčić in the LNHO}

China was not the first time that Štampar and Borčić collaborated with the LNHO. Their collaboration went back to the early I920s, when the newly founded LNHO threw itself with great enthusiasm into the fight against epidemics and the establishment of international public health standards. LNHO soon developed into an innovative institution that approached seriously the problem of the organization of public health services at the international level. It encouraged standardization, research and education, and built comprehensive international infrastructure. ${ }^{19}$ The processes that the LNHO initiated promoted the establishment of an intellectual community

the Kingdom of Yugoslavia, see Dugac Ž. Protiv bolesti i neznanja: Rockefellerova fondacija u međuratnoj Jugoslaviji, Zagreb, Srednja Europa, 2005; Dugac Ž. New public health for a new state: interwar public health in the Kingdom of Serbs, Croats and Slovenes (Kingdom of Yugoslavia) and the Rockefeller Foundation. In: Borowy I., Gruner W. (eds.). Facing Illnesses in Troubled Times: Health in Europe in the Interwar Years, Frankfurt am Main, Peter Lang, 2005, pp. 277-304.

18 In 1931, Štampar was dismissed from his position of the head of the Hygiene Department of the Ministry of People's Health and Social Policy of the Kingdom of Yugoslavia, because since the introduction of the dictatorship in 1929 he had been in conflict with the ruling elites. That conflict was the main reason why Štampar spent much of the 1930s overseas and why he became so active in the LNHO projects; his public health work in Yugoslavia was, for the most part, blocked. Štampar was joined by another political refugee of a sort, though from Austria, Professor Julius Tandler. Tandler was a well known advocate of social medicine, public health expert and professor of anatomy at the University of Vienna. Most importantly for his political status, he was a Social Democratic politician and an architect of public health and social welfare in the city government of 'red Vienna'in the 1920s and early 1930s, until its fall in 1934. Štampar attended Tandler's lectures on social medicine at Vienna's schools for adult education (Volkshochschulen) during his student days. He considered Tandler his teacher. In the 1930s, the LNHO managed to obtain an invitation for Tandler to teach anatomy at the Shanghai Medical School. This appointment resulted in an opportunity for Tandler and Štampar to socialize and to exchange their views on contemporary health problems. See more in: Dugac Ž, Svijet kao domovina: Andrija Štampar i njegova međunarodna aktivnost tridesetih godina XX. Stoljeća, In Dugac Ž, Pećina M. (eds.) Andrija Štampar: Dnevnik s putovanja 1931-1938, Zagreb, HAZU, Srednja Europa, ŠNZ Andrija Štampar, 2008, XV-LVIII).

19 Howard Jones N. International Public Health between the Two World Wars: The Organizational Problems, Geneve, World Health Organisation, 1978. On all of the LNHO activities, 
that could take on these new tasks. ${ }^{20}$ It all started with an informal meeting in London in 1919, when British, French and American representatives as well as the delegates of the Paris Office (previously International Office for Public Health) and the Red Cross League discussed plans for international health after the war. In the subsequent years, many international public health activities developed. So, headed by Ludwik Rajchman, the LNHO organized numerous programmes, meetings of international experts who studied various areas of public health and provided national governments with guidelines for future activities. ${ }^{21}$

Andrija Štampar and Berislav Borčić joined the organization in its early days. In March 1922 they represented the Kingdom of Serbs, Croats and Slovenes at the European Health Conference in Warsaw. The conference was of particular importance as it was the most important meeting by the newly founded LNHO ever since its London gathering. The conference was supposed to provide solutions for many problems of great importance to post-war Europe, such as protection from epidemics and especially from epidemic typhus that was spreading from Central Asia, Russia, Belarus and Ukraine towards Europe.

The conference elected three committees. One of them had the task of analysing the epidemiological status based on reports provided by national representatives of countries that were affected by epidemics. The second committee was charged with suggesting measures to countries bordering with Russia to ensure exchange of information concerning the prevention of the spread of epidemics. The third committee was supposed to produce a detailed programme for the LNHO's activities. Štampar was elected vice-president of the second committee. That committee presented to the assembly its resolution concerning an international sanitary convention, and suggested to use the extant Paris International Sanitary Convention as the foundation for a new one, to which additional points could be added. So, they proposed adding typhus and recurrent fever to the list of diseases that are subject to international regulations. They defined the need to sign bilateral agreements

see more in Borowy I. Coming to Terms with World Health: The League of Nations Health Organisation 1921-1946, Frankfurt am Main, Peter Lang, 2009.

20 Dubin M. D. The League of Nations Health Organisation, in: Weindling P (eds.) International organisations and movements 1918-1939, Cambridge, Cambridge University Press, 1995; Borowi, Iris. Coming to Terms with World Health: The League of Nations Health Organisation 1921-1946, Frankfurt am Main: Peter Lang, 2009.

21 Goodman N. M., International Health Organizations and Their Work, Edinburgh, Churchill Livingstone, 1971.; Borowi, Iris. Coming to Terms with World Health: The League of Nations Health Organisation 1921-1946, Frankfurt am Main: Peter Lang, 2009. 
between states and to regulate deadlines for reporting epidemics. Of particular significance and a proof of Štampar's influence was the committee's emphasis on expanding the scope to include other health problems, such as social hygiene, diseases such as tuberculosis, sexually transmitted, workplace-related and other diseases, as well as the exchange of experts. The committee furthermore stressed that the efforts to improve public health would go nowhere without public support. So they suggested setting the systematic health promotion and education as absolute priorities. All of these projects were realized by Štampar within the public health system of the Kingdom of Serbs, Croats and Slovenes, especially those related to popular health education. Under the auspices of the Zagreb School of Public Health, the Kingdom saw the emergence of comprehensive programmes based on popular health education using a variety of methods: lectures, courses, film screenings, public health events, as well as the involvement of local communities into various preventative programmes targeted towards the improvement of public and private hygiene, and the interruption of the chain of infectious disease transmission..$^{22}$

These two experts were, thus, active participants of one of the foundational conferences of the League of Nations Health Organizations, which set the course of development of the international health system not only between the wars but throughout the twentieth century. This important conference produced a strategy for international health, which no longer restricted itself to the old defensive principles of protection from epidemics using barriers and cordons, but expanded its activities to produce a joint attack on epidemics and — of particular significance—their sources. ${ }^{23}$

Štampar continued his active work in the LNHO in subsequent years. In 1926 he was a member of the Committee for Hygiene Education, and from 1929 of the Committee for Social Insurance. ${ }^{24}$ The 1930 annual report of the Health Organization named Štampar as a member of the Health (Hygiene) Board of the organization. In the same year, he was also mentioned as a

22 More in Ž. Dugac, Kako biti čist i zdrav: zdravstveno prosvjećivanje u međuratnoj Hrvatskoj, Zagreb, Srednja Europa, 2010.

23 Dugac, Ž. Svijet kao domovina: Andrija Štampar i njegova međunarodna aktivnost tridesetih godina XX. stoljeća. In: Andrija Štampar Dnevnik s putovanja 1931.-1938. Dugac, Željko; Pećina Marko (ed.) Zagreb, Hrvatska akademija znanosti i umjetnosti, Škola narodnog zdravlja «Andrija Štampar» Medicinskog fakulteta Sveučilišta u Zagrebu, Srednja Europa, 2008, XV-LVIII.; Report, European Health Conference, Warsaw 20-28 March 1922. LNHO Archives, Geneva.

24 Grmek M. D. ed. U borbi za narodno zdravlje, Izabrani članci Andrije Štampara. Zagreb, ŠNZ «Andrija Štampar» i Medicinski fakultet, 1966, 35. 
member of the Sub-committee for Preventive Medicine and the Committees of Public Health Experts and for Social Insurance. ${ }^{25}$

Together with Berislav Borčić, Štampar took an active part in the organization and work of some of the LNHO conferences, such as the meetings organized on the occasions of the opening of Schools of Public Health in Zagreb and in Budapest in 1927. These meetings brought together the leading public health experts of this period. ${ }^{26}$ They took active part in the meetings organized by the LNHO for directors of European Schools of Public Health such as the Paris meeting of 1930 that focused on the education of medical personnel and health promotion. ${ }^{27}$ In the same year, Štampar participated in a meeting in Dresden that also focused on health promotion. ${ }^{28}$ Also in 1930, Štampar undertook a study trip through the Netherlands and Scandinavian countries to investigate the organization of their national health systems. ${ }^{29}$ At the European conference about rural hygiene in 193I, Štampar lectured on the most effective methods to organize health service in rural areas. ${ }^{30}$ He continued his League of Nation service in 193I by helping the German Hygiene Museum in Dresden organize an exhibition on rural health. ${ }^{31}$

Berislav Borčić, a veterinarian and a physician, had worked on the protection from contagious diseases since the establishment of the public health system in the Kingdom of Serbs, Croats and Slovenes in igig. His first appointment was as director of the Pasteur Institute in Belgrade right after the First World War, which was followed by directorship of the Bacteriological (Epidemiological) Institute in Zagreb. With the establishment of the Hygiene Institute and School of Public Health in Zagreb in 1926, Borčić became the director of this important establishment that formed part of a network of institutions in numerous cities of Europe and North America, and the key local institution for international cooperation in this area. From its very beginnings, Borčić focused on the fight against contagious diseases. During the First World War and the time when the south of Serbia was ravaged by epidemic typhus, he worked at the Pasteur Institute in Niš. After the war he

25 Annual Report of the Health Organisation for 1930, A.7.1931.III, April 1931, p.60, 62, LNHO Archives, Geneva.

26 Letter Borčić to Norman White, 9.9.1927, R952/57565/41197, LNHO Archives, Geneva.; Provisional Program of Conference and Tour, 1.8.1927, R952/57565/41197, LNHO Archives, Geneva.

27 Health General, 8A/20164/3073, LNHO Archives, Geneva.

28 Health General, 8A/20827/3073, LNHO Archives, Geneva.

29 Letter Štampar to Boudreau, 24.10.1930, 8B/18878/1218, LNHO Archives, Geneva.

30 European Conference on Rural Hygiene 1931, Minutes, LNHO Archives.

31 Letter, Štampar to Rajchman, 28.5.1931, 8B/18878/1218, LNHO Archives, Geneva. 
put his efforts into measures against the introduction of plague-which in this period appeared in neighbouring countries--into the Kingdom of Serbs, Croats and Slovenes. Borčić organized stringent quarantine, for example in then-important port of Martinšćica in the northern part of the Croatian Adriatic coast. He also participated in the efforts to combat epidemic typhus in the Kingdom in the early I920s. In agreement with Frederic Russel and Simon Flexner from the Rockefeller Foundation, the LNHO paid for Borčić's study trip to the US in $1924 .{ }^{32}$ Borčić used this opportunity to visit various medical institutions on the West Coast. ${ }^{33}$ A letter that he sent to Rajchman upon his return to Europe in August 1924 reveals the significance of this study trip to Borčić's career. ${ }^{34}$ Borčić's collaboration with the LNHO continued in subsequent years so in 1926 the same organization supported his study trip to the London School of Tropical Medicine in the UK, and in 1928 he studied rural hygiene in Germany, Denmark, Netherlands and Belgium on behalf of the LNHO. ${ }^{35}$

As I mentioned, I920s were the golden years of public health in the Kingdom of Serbs, Croats and Slovenes. Both Borčić and Štampar completed internationally recognized and much applauded projects. By the end of this decade they had both earned international recognition. So in I929 Borčić visited Greece with a LNHO committee to study local health conditions, institutions and personnel, and to suggest guidelines for further development. In I930, Borčić organized a course for future collaborators of the new Greek public health service. The course was organized because the LNHO requested the Zagreb's School of Public Health to set up annual courses in public health for international travel grant recipients. ${ }^{36}$ In the same year, the LNHO charged Borčić with another comprehensive and demanding task: to go to China and to organize a central hygiene institute in the Chinese capital, Nanking (Nanjing). The institute was to become the core of a future

32 Letter, LNHO to B.Borčić, 21.5.1924, R852/28416/26189, LNHO Archives, Geneva; Letter, Borčić to Rajchamn, 22.4.1924, R852/28416/26189, LNHO Archives, Geneva.

33 A letter from Borčić to Rajchman dated 20 November 1923 shows that he intended to visit an important American centre for vaccine production, Hygienic Laboratory dr. George McCoy, in Washington (Borčić to Rajchman, 20.11.1923, R852/28416/26189, LNHO Archives, Geneva.) Rajchman announced Borčić's visit to McCoy as part of a programme of exchange of bacteriologists. (Letter, Rajchman to McCoy, 7.12.1923, R852/28416/26189, LNHO Archives, Geneva).

34 Letter, B. Borčić to L. Rajchman, 21.8.1924, R852/28416/26189, LNHO Archives, Geneva.

35 Letter Borčić to Rajchamn, 21.9.1926, R928/51579/34384, LNHO Archives, Geneva.; Letter Rajchman to Borčić, 26.6.1928, R928/51579/34384, LNHO Archives, Geneva.

36 Milovanović V. (ed). Medicinski godišnjak Kraljevine Jugoslavije. Beograd, Jugoreklam, 66. 
hygiene institution for the entire country. ${ }^{37}$ That mission would keep Borčić busy until I938, when China fell victim to the colossal Japanese invasion. ${ }^{38}$

\section{Project China}

The League of Nation's Health Organization began its negotiations about collaboration with China as early as 1925, when the League opened its Far Eastern Bureau in Singapore. The role of this office was to collect information about the spread of cholera, plague, smallpox and yellow fever in the Far East and to introduce epidemiological intelligence in numerous parts in this part of the world, as well as a quarantine system that would meet European requirements. This collaboration in the area of sanitary control in maritime ports was the beginning of a much larger collaboration between the LNHO and Chinese government, which eventually resulted in the introduction of Western medicine and the Western model of public health into China. ${ }^{39}$ In I928, Rajchman visited China and opened negotiations on the collaboration in the area of maritime quarantine, medical and sanitary institutions, as well as medical training and anti-epidemic work. Because of the unrest in the country, it was only in I930 that Rajchman succeeded in negotiating direct action. ${ }^{40}$ Accepting the invitation of the Chinese president, Rajchman left for China in 1930 to discuss which public health campaigns would take place, and which staff should be hired for them. ${ }^{41}$ As a result of these discussions, in the same year Berislav Borčić arrived in the country to help set up the Central Field Station at Nanking (Nanjing). Borčić thus became the chief health advisor to the Government lead by Chiang Kai-shek. The collaboration of the LNHO with the Chinese government was furthermore expressed in the appointment of Dr J. Hen Liu, Chinese health minister, to the post of

37 Belicza B, Rastija M. Prilog poznavanju života i rada dra Berislava Borčića (1891-1977), eksperta Lige Naroda i Svjetske zdravstvene organizacije. Saopćenja 30, 1984, 129-144.

38 First mission lasted from 1930 to 1932; second from 1933 to 1935 and third mission from 1935 to 1938 (see Belicza, Rastija).

39 The LNHO was not the only organization that introduced Western medical and public health standards into China, a country with its own medical tradition. Missionary associations, individual doctors and European colonies (at treaty ports) all had been promoting and using Western medicine for decades. Also in the interwar period the Rockefeller Foundation launched its Chinese programmes of which the largest and most significant was the establishment of the Peking (Beijing) Medical School. The Foundation invested heavily into setting up Western medical training.

40 Borowy I. Thinking Big - League of Nations Efforts towards a reformed National Health System in China. In: Borowy I. (ed.), Uneasy Encounters: The Politics of Medicine and Health in China 1900-1937, Frankfurt am Main, Peter Lang, 2009, 205-228.

41 Annual report of the Health Organisation for 1930, p. 22. Archives of the LNHO, Geneva. 
a vice-chairman of the Health Committee of the LNHO in I93r. Dr J. Hen Liu also became a member of the Sub-Committee on the Budget of the Far-East Bureau of the LNHO, as well as the member of the Opium Commission. ${ }^{42}$ The Nanjing Central Field Station, a new public health centre and a counterpart of the European schools of public health, became operational as early as I93I. ${ }^{43}$ Its employees were a mixture of local Chinese public health workers and international experts. ${ }^{44}$

Minutes of the Health Committee of the LNHO meeting in May I93I show that the Chinese minister of health through his representative Dr Wu Lien-teh, director of the National Quarantine Service, informed the committee members that the Chinese Minister of Finance T.V. Soong approved the budget for the three-year plan for the Chinese National Health Service. Wu Lien-teh also requested the Health Committee of the LNHO to send to China experts, and "particularly Dr. Borčić, Dr. Park ${ }^{45}$ and Dr. Faber ${ }^{46}$ have rendered us invaluable service." 47 In the same year, Borčić in China was joined by Štampar, first in his capacity of a LNHO expert and then as an advisor to the Chinese government. ${ }^{48}$

42 Annual report of the Health Organisation for 1930, pp. 60-63. Archive of the LNHO, Geneva.

43 The Minutes of the Seventeenth Session of the Health Committee in 1931 show that the Chinese government slated the Central Field Station at Nanjing as one of the technical services under the new National Economic Council. The renovation of the old building of the former Ministry of Health, connected with the Ministry of Interior and which had been used for the Station, would be completed in 1932. (Minutes of the Seventeenth Session of the Health Committee, 4-8.5.1931, LNHO Archive, Geneva).

44 Borowy I. Thinking Big - League of Nations Efforts towards a reformed National Health System in China. In: Borowy I. (ed.), Uneasy Encounters: The Politics of Medicine and Health in China 1900-1937, Frankfurt am Main, Peter Lang, 2009, 205-228.

45 Under the guidance of Dr Charles Park from the Far Eastern Bureau, a campaign was launched between May and September 1930 to vaccinate 500,000 people as well as to set up measures to improve the supply of drinking water by means of artesian wells; destroy flies; protect food supplies; and improve laboratory investigations, arrangements for prompt notification and hospitalization and popular education. (Borowy I. Thinking Big - League of Nations Efforts towards a reformed National Health System in China. In: Borowy I. (ed.), Uneasy Encounters: The Politics of Medicine and Health in China 1900. 1937, Frankfurt am Main, Peter Lang, 2009, 205-228).

46 The mentioned Knud Faber, professor of medicine at Copenhagen University, spent the period between September and December 1930 writing a report on medical schools in China for the LNHO.

47 Minutes of the Seventeenth Session of the Health Committee, 4-8.5.1931, LNHO Archive, Geneva.

48 Dugac Ž. Andrija Štampar (1888-1958): Resolute Fighter for Health and Social Justice. In: Borowy I., Hardy A. (ed.), Of Medicine and Men: Biographies and Ideas in European Social Medicine between the World Wars. Frankfurt am Main, Peter Lang, 2008. 


\section{The Borčić-Šttampar duO In China}

As mentioned previously, Borčić arrived in China first, in 1930, and Štampar followed him in 193I. These two experts would stay in China, with few interruptions, until the end of the r930s. As early as 1930 Stampar knew that Rajchman would send him to China, yet his first journey across the ocean was a westward one. In September 193I and at the invitation of the Rockefeller Foundation (as well as in his capacity of the LNHO advisor), Štampar left for the US and China. The Foundation invited him to take a tour of the best known American universities and public health projects, to overview activities taking place in the States and to provide his feedback. The LNHO requested him to review health administration and costs of health services, as well as the means of production of hygienically acceptable milk. ${ }^{49}$ During Štampar's stay in the US, a telegram from Borčić, stationed in Nanjing, arrived, informing Štampar that funds for his trip to China had been approved, and that he should plan a trip via Honolulu and Japan. ${ }^{50}$

Unfortunately, Borčić did not write a travel diary during his time in China, so sources for a study of his career are scant. In contrast, Štampar wrote a diary from 1931 to 1938 in which he described in great detail his experiences during his travels. This diary is an excellent source for the study of public health—as well as national politics—of China in this period. ${ }^{51}$ It tells us that Štampar disembarked in Shanghai on 20 January 1930. It was his first visit to that country and it took place in a particularly inauspicious moment, while Japanese bombs were falling on Shanghai, river Yangtze flooded and its tributaries caused massive damages in the area inhabited by $25 \mathrm{mil}-$ lion people. Floods brought waves of refugees who, hungry and lacking any

49 More in: Dugac, Ž. Svijet kao domovina: Andrija Štampar i njegova međunarodna aktivnost tridesetih godina XX. stoljeća. In: Andrija Štampar Dnevnik s putovanja 1931.1938. Dugac, Željko; Pećina Marko (ed.) Zagreb, Hrvatska akademija znanosti i umjetnosti, Škola narodnog zdravlja «Andrija Štampar» Medicinskog fakulteta Sveučilišta u Zagrebu, Srednja Europa, 2008, XV-LVIII.

50 Telegram, Borčić to Štampar, 8.12.1931. Correspondence, Personal fund A. Štampar HR HDA 831, Hrvatski državni arhiv (Croatian State Archive), Zagreb.

51 In his rather personal diary Štampar recorded some information about the life and career of Berislav Borčić in China. For instance, he wrote about the life of the family Borčić, thus providing a more complex perspective on the conditions in which his colleague worked. So, during his second trip to China Štampar wrote: "Mara (Borčić's wife) is sickly and she has lost much weight, she is feeling poorly both physically and mentally... Their apartment is lovely, in a peaceful neighbourhood outside the town. They live in a two-storey villa in a spacious walled courtyard. There is grass in the courtyard so the children can play. They do not go out at all; Berica (Borčić) goes to the office and comes back home late. Mara says they live in a golden cage." (Ž. Dugac, M. Pećina (ed.) Andrija Štampar, Dnevnik s putovanja 1931-1938. Zagreb, HAZU, Srednja Europa, ŠNZ «Andrija Štampar», 2008, 194). 
material goods, sought shelter. This situation further increased threat from dysentery, cholera and malaria. ${ }^{52}$ At that time, Borčić and his new European reinforcement, headed by the Romanian hygiene professor Mihai Ciuca, organized field units in ravaged, critical areas. The tasks of these units included organizing immunizations and various health campaigns..$^{53}$

Soon after his arrival in China, Štampar got in touch with John B. Grant, professor of hygiene at Peking Union Medical College, established, as previously mentioned, by the Rockefeller Foundation..$^{54}$ Grant was a remarkable connoisseur of China, and an expert in the areas of hygiene and social medicine. Štampar and Grant soon found a common language and started a collaboration that would last for the entire duration of their stays in China. ${ }^{55}$ Grant introduced Štampar with one of the most interesting public health projects of contemporary China not launched by the LNHO but by local experts, oriented towards modern public health, yet well acquainted with local conditions and Chinese rural traditions. This was Ting Hsien project, a model-village that accommodated a unique project on hygienic and educational improvement of the village. The project was based on ideas of the legend of Chinese public health and education, Dr James Yen. ${ }^{56}$ Štampar was highly

52 Štampar Andrija, Zdravstvene i socijalne prilike u Kini, Liječnički vjesnik, 59, 1937, 323. 327, a translation of a report in English originally published in the Bulletin of the Health Organisation of the League of Nations, 5/1936, 1090-1126.; Ž. Dugac, M. Pećina (ed.) Andrija Štampar, Dnevnik s putovanja 1931-1938. Zagreb, HAZU, Srednja Europa, ŠNZ «Andrija Štampar», 2008.

53 More in Borowy I. Thinking Big - League of Nations Efforts towards a reformed National Health System in China. In: Borowy I. (ed.), Uneasy Encounters: The Politics of Medicine and Health in China 1900-1937, Frankfurt am Main, Peter Lang, 2009, 205-228.

54 John B. Grant lived in China between 1921 and 1938 and accumulated an enormous experience in public health in this country. He collaborated with the Ting-Hsien programme, where his students were sent for their field practice. His relationship with Stampar was very close: they collaborated and travelled through China together. He was unique among the professorial staff of the Peking Medical School, as well as among the Rockefeller Foundation, for his passionate advocacy of social medicine and social programme. He was called a medical Bolshevik. (See more in Brown Bullock, M., An American transplant, The Rockefeller Foundation and Peking Union Medical College, University of California Press, Berkeley, 1989).

55 Ž. Dugac, M. Pećina (ed.) Andrija Štampar, Dnevnik s putovanja 1931-1938. Zagreb, HAZU, Srednja Europa, ŠNZ “Andrija Štampar”, 2008.

56 James Yen was an educator and an organizer of the cultural, health and economic revival of the Chinese village. His project took place from 1926 to 1937 in Ting Hsien. The project (also known as the experiment) in Ting Hsien used education through so-called people's schools to promote various innovations, from the breeding of hybrid pigs and agricultural co-operatives to cultural performances. All of these were very similar to the projects that Štampar and his colleagues conducted in the Kingdom of Yugoslavia. Public health work was of particular importance and the project educated an original kind of rural medical assistants whose role was to assist physicians and other medical staff in those regions where 
impressed by this project; he returned to Ting Hsien on multiple occasions, because it was based on similar principles to the programme that Štampar launched and managed in the Kingdom of Yugoslavia in 1920 s. ${ }^{57} \mathrm{~A}$ man who at the time was a junior project collaborator, Dr C.C. Chen (Ch'en Chihch'ien), later undertook further education in public health in the Kingdom of Yugoslavia and especially in the School of Public Health. Upon his return to China, he became a leading architect of the Chinese public health experts and he continued his work after the Second World War. ${ }^{58}$

As early as his first visit to this large and populous country in which the LNHO hoped to establish a modern healthcare system, Štampar observed the difficult social situation of the Chinese population. For him, this was the main obstacle to any improvement in the public health. In his later reports, and in his more general considerations about public health in the contemporary world, Štampar used his Chinese experience to argue that the work on the improvement of public health is doomed to fail if the standard of living falls below the existential minimum. His study of economic and social conditions in this country led him to believe that eradicating huge social differences-and especially exploitation by large landowners-and the establishment of a just social order were of essential importance. ${ }^{59}$

While the first visit of China was a training trip of a sort, Štampar's next trip, in 1933, was in the capacity of a League of Nations expert, to help the Chinese government organize their healthcare service. Štampar placed himself fully at disposal of the Chinese authorities and travelled to the parts of China rarely (or never) visited by Europeans. He travelled to the Chinese Far

professional medical staff was scarce. The Ting Hsien project attracted the attention of the entire world, and especially of Štampar, for whom the new methods of rural development independent from the control of the central government, revolution or foreign investment were of particular interest. The control of the central government and political turbulences played a key role in the slowing down of the public health programmes in the Kingdom of Yugoslavia following the establishment of the King Alexander's dictatorship in 1929 (Ž. Dugac, M. Pećina (ed.) Andrija Štampar, Dnevnik s putovanja 1931-1938. Zagreb, HAZU, Srednja Europa, ŠNZ «Andrija Štampar», 2008).

57 The village Mraclin near a Zagreb (Croatia) was also a model village, an experimental station for trying out new methods of rural hygiene. It was also the training site for students of the Zagreb School of Medicine, as well as international visitors sent to the Kingdom with the support of the RF and LNHO.

58 Štampar recommended Chen for further education overseas. In 1935 the League of Nations supported Chen's trips to the Soviet Union, Kingdom of Yugoslavia and India. In his later book, this highly active Chinese physician wrote how impressed he had been with the achievements in the field of public health in rural Croatia. See Chen C.C. Medicine in Rural China. Berkeley, University of California Press, 1989.

59 See Ž. Dugac, M. Pećina (ed.) Andrija Štampar, Dnevnik s putovanja 1931-1938. Zagreb, HAZU, Srednja Europa, ŠNZ "Andrija Štampar”, 2008. 
West, where he would return several times in the following years. This was the part of China that would become the site of Štampar's most intense social medical institutional activities. In those provinces forgotten by the Chinese administration, Štampar would repeat the feats he had once accomplished in the Kingdom of Yugoslavia: establish new social-medical institutions and schools for training medical personnel.

His journey began with a trip across the Yellow River and river Wei down the route towards the old imperial city of Xi'an, the capital of Shaanxi province. He toured the district of Chang'an and the surroundings of Xi'an, before taking an air trip to the capital of Gansu, Lanzhou. He then returned to Nanjing and Shanghai to meet one of the most influential people of the period, Tse-Ven Soong, who in the Nationalist Government served at various positions: vice-president of the government, minister of finance and the governor of the Central Bank of China. Štampar established close collaboration with him. ${ }^{60}$ Having read Štampar's reports, Soong decided to accompany him to western provinces, first to Xi'an, then Lanzhou and then further, to the province of Qinghai (historical name of Kokonor, created out of northern Tibet) and its capital Xining. Stampar then flew along the course of the Yellow River and then crossed the Gobi desert at Alxa/Alashan, a mountain range in northern China between Ningxia and Inner Mongolia, arriving into the province Ningxia/Hui. The journey ended with their return to Xi'an and then Beijing.

Soon after this trip, Štampar left for his third journey to the China's Far West. Soong granted him sufficient financial support to establish new medical institutions in the four provinces. He was going to start with the provincial health centres and schools for lower medical personnel. He found himself in Xi'an and the Yellow River area again. Then he left for Lanzhou and Xining, and again visited Ningxia. ${ }^{61}$

60 Tse-ven (Tzu-wen) Soong, a prominent businessman and politician. Soong's brothers-inlaw were Sun Yat-sen, Chiang Kai-shek and the powerful financier H. H. Kung. During his stays in China, Štampar established close collaboration with Soong and managed to get this powerful man interested in health programmes in the Chinese Far East. Soong provided an adequate financial support for these initiatives. In addition to the intense professional collaboration, Štampar also developed a personal attachment to Soong and devoted beautiful and touching parts of his diary to his friend. (More in: Ž. Dugac, M. Pećina (ed.) Andrija Štampar, Dnevnik s putovanja 1931-1938. Zagreb, HAZU, Srednja Europa, ŠNZ «Andrija Štampar», 2008).

${ }^{61}$ Following his tour of the Far North-West, the site of the most important programmes, Stampar decided to see other parts of the country too. He travelled to the South-East: Hong Kong, then Canton (Guangzhou). In the Macau outskirts he hoped to see the 'model district' Chungshan but that project had failed, due to political reasons. From Guangdong 
In the following year, 1935, Štampar briefly visited Zagreb and then returned to China to commence a new trip to far Chinese provinces. ${ }^{62}$ From Shanghai he travelled to the capital Nanjing. Then, wanting to see how the institutions that he had established in the past year in the north-west were doing, he launched his fourth journey through north-western provinces. ${ }^{63}$ He flew to Xi'an, then Lanzhou and finally Ningxia. After this trip he left for Beijing and then again to see Dr C. C. Chen in Ting Hsien. ${ }^{64}$ His travels then took him to Jiangsu and Canton (Guangzhou), to study public health conditions and devise suitable work programmes. Finally, from Hong Kong, he launched a new tour, taking him to the south-western provinces and the French colony of Indochina. He travelled by boat and then continued by train from Hanoi back to China, to the southern province of Yunnan. From the capital Yunnan (Kunming) he visited tin mines 150-200 kilometres away, as well as the mines in the southwestern region of Yunnan, near Kochiu. This trip was a moving experience, as Štampar encountered terrible forms of human exploitation, near-slavery work conditions, that would later become topics of his writings and of which he would inform the authorities. Deeply touched, he returned to Indochina and then continued by car towards Nanning, the capital of Guangxi-Zhuang. ${ }^{65}$

he travelled further south to the province (now autonomous region) Guangxi-Zhuang and its capital Nanning. Following his tour of Nanning and its area, he flew over the Hunan province to is capital Changsha, from where he travelled by train to Hubei, and then again to Ting Hsien, Shanghai and Nanjing. Finally, he boarded a ship to Europe in Hong Kong in the late autumn of 1934 (See Ž. Dugac, M. Pećina (ed.) Andrija Štampar, Dnevnik s putovanja 1931-1938. Zagreb, HAZU, Srednja Europa, ŠNZ “Andrija Štampar”, 2008). Ž. Dugac, M. Pećina (ed.) Andrija Štampar, Dnevnik s putovanja 1931-1938. Zagreb, HAZU, Srednja Europa, ŠNZ “Andrija Štampar”, 2008.

63 Štampar wrote that it was his third trip to the north-west, obviously meaning Ningxia, because it was his fourth trip to Shaanxi and Gansu.

64 Ibid.

65 He then returned to Hong Kong, Shanghai and Nanjing, taking Blue Express to the provinces of Jiangsu and Shandong and then northwards for his fifth visit to Beijing. From Beijing he left for the province of Shanxi and its capital, Taiyuan. Then via the province of Hubei he continued back to Beijing-Nanjing - Shanghai. His next trip was to Hangzhou, the capital of the Zhejiang province. Then he returned to Jiangxi province, staying in the capital Nanchang and neighbouring villages. He travelled to the rural areas in Sichuan, Chongqing and Sichuan's provincial capital Chengdu. This tour was followed by another trip to the north-west, Lanzhou and Xi'an, then back to Nanjing, where he met Madame Chiang twice. This was followed by a trip to Fujian, more precisely to Amoy (Xiamen) in the south of the province. He also visited Zhangzhou and the district of Longhai in southwest Fujian. He returned to Nanjing for the last time, then to Beijing, boarding a ship to Dalian and then Harbin, then from Manzhouli in the puppet-state of Manchukuo with the Trans-Siberian Railway through the Soviet Union back to Zagreb (Ibid.). 
Štampar's trip through China was exhaustive. Along with learning the geography of this enormous country, he was also getting himself acquainted with the people and their work. For Štampar meeting common people, coolies, and peasants was of particular importance. By observing the rural life, Chinese mothers, children, peasants working in fields, he established the foundations of his knowledge and tried to understand their needs. By developing close relationships with all the enthusiasts in the field of public health, local medical professionals and teachers, Štampar constructed a network of collaborators that, on one hand would be sensitive to local needs, and on the other accept the principles of new public health work. Štampar admired both the common people of China, whom he described as having unusually strong life power, but also Chinese physicians who in such a short time managed to achieve so much. These included Dr James Yen, C. C. Chen, and Marion Yang, the pioneer of women and child's health and the organizer of the modern midwifery in China. Štampar's teachers included a range of people, from peasants to the philosopher Hu Shih, with whom he socialized and exchanged observations. ${ }^{66}$ Obviously, Štampar built relationships not only with the common people and local medical professionals and intellectuals, but also with persons of great power. Along with T. V. Soong, Stampar also kept in touch with Mei-Ling Soong, also known as Madame Chiang Kai-shek. In his diary he wrote about her: "In this respect I admire this interesting woman: she is neither shy nor conceited, she is honest and recognizes her own mistake and ignorance. She was educated overseas in very good institutions but, of course, her education is not for China. She knows that some things are wrong but she does not know what. She lacks the basic understanding of rural issuesand these are of course of outmost importance for the future of the country-so she constantly falls under this or that new influence. There is no doubt that she is under my influence at the moment, but who knows for how long. She certainly has influence upon her husband, but I do not think she has the strength to make her ideas a reality." ${ }^{67}$ These observations reveal the problem. A woman who, with her husband, created many initiatives in her own country, could not understand the real state of affairs - the real problems—of the Chinese village; she was educated overseas, prone to external influences and finally too weak to face the problems and establish a clear vision of action. In their conversation Štampar stressed the example of Dr Yen's Ting Hsien project, which was very good, but was never transformed from a private initiative into part

\footnotetext{
Ibid.

67 Ibid. 620.
} 
of public administration. Štampar warned Madame Chiang Kai-Shek that China hosted many programmes the goal of which was to improve rural conditions, how these cost a great deal of money, yet they lacked unity, a shared plan that would lead to a common goal, and, most importantly, most of these programmes were based on similar examples tested in other countries, yet these had different traditions, different population, and different social economic conditions from China. Here again Štampar stressed the poor fit of foreign principles to Chinese circumstances, and the need to turn to local specificities.

Štampar's obsession with rural China and the need to do something constructive about it is witnessed by the following observation in his diary: "That day I visited the secretary of the People's Economic Council, who received me to hear about my impressions from the trip through northwestern regions. He was exceedingly polite and listened to me with great attention. He called me a 'peasant advocate' and asked how much money I wanted on that day. I told him what I wanted and he immediately agreed to pay $\$ 2000$ to enlarge a midwifery school in Sian (X'an) and $\$ 800$ for a disinsection station in the health centre in Lancau (Lanzhou). As we parted he said he cared a great deal for me because I fought for peasants, and there were few like me in his country." ${ }^{\circ 8}$

But wishes and enthusiasms of public health workers were one thing, and politicians' interests and ideologies another. The rift between these two camps is described in the following observation that Štampar made, which is important for the analysis of the political surroundings in which Rajchman hoped to establish collaboration with the Chinese government, and in which Borčić and Štampar were supposed to work: "I spent the afternoon with Rajchman who is in terrible trouble. He told me about the four personalities at the centre of the Chinese world: the Marshal Chiang Kai-shek, who has the army and supports the government; Wang Ching-wei, the minister president and the political leader; the marshal cannot work without him but Wang Ching-wei knows he depends on the marshal's mercy. T. V. Soong is the fin ance minister and the most capable person in the government, but he was overseas for half a year so the Nanjing elite decided that China could function without him. He also made a huge mistake when he argued that dictatorship is an excellent tool for solving problems. His argument appealed to the marshal so much that the latter decided to put it into action, but the marshal also thinks he should be the dictator and no one else. This caused the crisis and the finance minister has been in trouble ever since, because the marshal is

68 Ibid. 624. 
trying it kick him out of the government, not so much because of the dictatorship, but because the finance minister will not give enough money for the anti-Communist campaign that the marshal has been trying to launch for months, but he has not been able to do so. The Communist uprisings in China are nothing but the rebellion of peasants who want land and want to be free from their rural and urban masters from whom they lease the land and pay the privilege not just in money but also in blood. It is obvious that this kind of Communist uprisings will be settled not with guns, airplanes and cannons, but with land distribution. Sun Fo is the fourth factor in the government. He has no talents except being the son of Sun Yat-sen, so the son of the great father, and because of this family connection he obtained the post of the president of the legislative committee. No law can be enacted without his approval; when he wants to stop a law, he simply leaves for Shanghai where he cannot be found. These are the circumstances in which Rajchman undertook the difficult task of helping this giant country get out of its troubles and make a step forward. His vision is sharp and he is able to find his way in tough situations. He says that the first problem is to solve the political crisis, because no work can be undertaken in such circumstances. I agree with him. So the poor man is travelling between Shanghai and Nanjing, then to Nanchang to hear the marshal's latest opinions and to settle the wars between the camps." 69

Following Štampar's departure, Berislav Borčić remained in China until I938. ${ }^{70}$ In these last years of his stay in China Borčić increasingly came into contact with the problems of political conflicts and the growing threat of the war. The difficult conditions in which he worked are depicted in the letter that Dr Ivo Kuhn from Belgrade sent to Andrija Štampar in November 1937. In this letter we can see the politics manipulating a medical report written by Berislav Borčić, on the examination of the Chinese who died during the

69 Ibid. 192-193.

70 During his long stay in China, Berislav Borčić inevitably neglected his work for the School of Public Health in Zagreb. His Zagreb colleagues hoped he would return to his home institutions. During this period, this institution was in an extremely difficult situation because the state failed to support it financially, and the grants provided by the Rockefeller Foundation were insufficient to pay for all the work that it did. For instance, in this period the school began to produce Neosalvarsan, which not only required additional funds, but also great diplomatic skills from the school management, because the central administration in Belgrade was trying to hinder the production in the Zagreb laboratory in order to launch such a business in Belgrade. In July 1938, Borčić took over the management of the School of Public Health, which was of great importance not just for the school but also for the Rockefeller Foundation. The latter was involved in encouraging the Neosalvarsan production as well as planned investments to enlarge the nursing school in Zagreb. More in: Dugac, Željko. Protiv bolesti i neznanja: Rockefellerova fondacija u međuratnoj Jugoslaviji. Zagreb, Srednja Europa, 2005. 
Japanese attacks: "On this occasion he gave me the second document ${ }^{71}$ in which the minister of foreign affairs presents the submission by the Chinese delegate to the League of Nations, in which the latter refers to Berica's statement that some Chinese were injured by the Japanese poisonous gases, and is asking the secretary to distribute this document to all members of the League of Nations. Berica statement is a testimonial signed by the head of the Nanjing hospital, in which it is confirmed without doubt the findings of poisonous gas and dum-dum bullets. Our Ministry of Foreign Affairs added that, if we were in touch with Berica, we should let him know that such statements could be used in propaganda and for accusatory purposes, and because Yugoslavia had a good relationship with Japan, he should refrain from issuing such statements in future."72

\section{REPORTS AND OPINIONS}

Upon his return to Europe, Štampar reported to the LNHO about his I934 enterprise carried out with the approval and support of the National Economic Council in four provinces: Shaanxi, Gansu, Qinghai and Ningxia. Provincial health centres were established in capitals of these provinces, while a chain of smaller institutions (hsien-centres) was planned to be built in rural areas. So in Shaanxi a provincial health centre, a school health centre and a midwifery school were established. The new Gansu provincial health centre consisted of an 80-bed hospital, midwifery school, department of maternal and child health, department of school medicine, outpatient units, and the department of public health and industrial hygiene. Provincial health centre in Qinghai and Ningxia were established on the same model.

In the following year, 1935, the Yunnan government requested from the people's health administration to establish a provincial health centre. Following a study trip in that province, Štampar recommended other provinces to establish a health organization using a similar model, and also suggested a special health organization for the tin-mining regions where miners suffered poor health, and adults as well as children were subjected to near-slavery conditions at work. In the same year, 1935, much of the efforts concentrated upon the Sichuan province, the battleground of various

71 In his letter to Štampar, Ivo Kuhn wrote about various events that took place in the Ministry of Social Policy and Public Health. He wrote how "Steva" (obviously the Minister of Health, Stevan Ivanić) showed him the document that referred to the statement produced by Berislav Borčić, or "Berica".

72 Letter Kuhn to Stampar, 1.11.1937, Personal fund A. Štampar HR HDA 831, Hrvatski državni arhiv, Zagreb. 
military fractions and communists. Sichuan had one hospital and the medical school by the West China Missionary Union, which included the only school of dentistry in China. Štampar was surprised by the scope of the work of the school supported by five Protestant missionary associations, especially in popular health education. So he suggested to the government to prepare a plan of collaboration with the extant Christian mission, which would avoid duplicating medical institutions. Finally, before his departure from China, Štampar was charged with advising the government of the province of Fujian - the province with the strongest Communist movement-on the establishment of health system. In his Fujian report, Štampar emphasised the problem of drug (heroin and morphine) trade, especially from the island of Formosa (Taiwan), because the islanders enjoyed extraterritorial privileges. Štampar stressed the danger of infection with non-sterile needles used by drug addicts. Fujian too had some health infrastructure, such as a midwifery school and a health centre. The hospital was under construction so Štampar suggested a standardized programme as well as the integration of the extant institution into the provincial health system. He also recommended establishing a medical school in the University of Amoy (Xiamen). Fujian was affected by plague, so Štampar advised collaboration with the national quarantine service to protect the province from further infection. He emphasized that the plague arrived from the inland foci rather than the sea, so he suggested intensifying international collaboration in this area. ${ }^{73}$

In the mentioned report submitted to the LNHO in 1937, Štampar paid special attention to the largest problems that appeared in the course of formation of the new public health system in China. Štampar stressed that the success in most areas of public health, and especially rural hygiene, depended on economy. The problems were linked to agriculture, predominantly small farms, high rents, debts and high interest, all leading to further pauperization of Chinese farmers. Their lives were further aggravated by periodical natural catastrophes, such as floods and draughts, and loss of income when attempting any additional production, such as weaving, because the state imported cheaper ready-made cloth. One way out was provided by mining, but this branch of industry was plagued by slavery relationships between business owners and workers. Solving health and hygiene problems was not possible without tackling economic problems. So, improving public

73 Štampar Andrija, Zdravstvene i socijalne prilike u Kini, Liječnički vjesnik, 59, 1937, 323. 327. (Published in English in the Bulletin of the Health Organisation of the League of Nations, 5/1936, 1090-1126). 
health could not be achieved if the standard of living fell under the existential minimum.

Štampar further reported that he had advised provincial governments in the provinces he had visited to pay attention to the rural population. In his view, rural health centres were the most important cogs of the health system; the purpose of all other institutions was to serve their needs. Provincial health centres in provincial towns were supposed to serve their urban communities but also to supervise and support rural health centres. ${ }^{74}$

Stampar furthermore stated that in the Chinese administration health service was within the remit of provincial authorities, while the central health administration outlined broad principles of health politics and supported local governments. Chinese provinces were thus meant to organize health services in accordance to the plan drafted by the People's Health Administration. According to that plan, the health centre was meant to be the central provincial medical institution and the supervisory body for all other health institutions in the province. Provincial health centres were supposed to include diagnostic laboratories, a hospital, midwifery school, department of maternal and child health, department of school health, a school and general outpatient clinic. They were set up using the model launched by Štampar in the Kingdom of Serbs, Croats and Slovenes in the Ig20s, with one improvement and exception that for long time could not be implemented in Yugoslavia because of the continuous tendencies of the Belgrade to centralize administration: administrative independence of provinces that followed nothing more than general instructions issued from the centre. ${ }^{75}$ All local institutions were permitted to use the central government laboratories (such as those in Nanjing and Beijing) and were supplied with sera and vaccines from these institutions. In this way vaccination programmes against smallpox, cholera and abdominal typhus could be carried out. The production of vaccines was launched and supervised by Berislav Borčić.

Štampar paid significant attention to medical education. He wondered if modern-and, by necessity, expensive--medical schools are suitable for Chinese circumstances, and whether they produce physicians able to serve the people. His answer was that modern medical schools in China are expensive; they produce few physicians; and to pay off the costs of the education,

74 Ibid.; League of Nations, Minutes of the $96^{\text {th }}$ Sitting of the Council, 25 January 1937, LNHO Archive. Geneva.

75 It was only with the formation of provinces (Banovinas) in the late 1930s that health administration went on the local level. 
most graduates opened private practices in cities or took positions in larger medical institutions. In this way, the majority of these graduates did not help Chinese peasants. Yet at the same time, Štampar argued, cheaper schools were no solution either, because their inadequate equipment and opportunities for clinical training could not provide education at a satisfactory level. Stampar objected to the establishment of two kinds of medical schools in China, one kind for the elite and the other, cheaper and lower quality, for peasants. As early as his student days, in his IgII article on Social medicine he argued that "While before and to a large extent today too, successes and benefits of modern medicine were enjoyed by the rich, at the present time the goal is for science and its practical outcomes to become a good shared by all members of the society". ${ }^{76}$ So, in his view two separate medicines, one for the poor and one for the rich, should not exist.

Štampar's critique of medical education in China was supported by the Rockefeller representative Selskar Gunn. In his diary, Štampar wrote: "Gunn is very critical of the work of the Foundation that so far had invested around 40 million of gold dollars in various institutions and aid programmes. Yet results are so poor that this may be considered the worst investment in the world... we talked a lot about the educational system creating intellectuals whose upbringing alienates them from the needs of their own country. He can see that institutions need help so that they can train students into good and capable workers in rural areas and outside cities, because the fate of China depends on the advancement of villages rather than towns. So he is planning to suggest to the Foundation an entirely new programme of activity, which would involve systematic assistance of Chinese institutions in the new direction and training new people to fulfil the real needs of Chinese peasants. In this way, intelligentsia could be used for the most pressing needs. ${ }^{77}$

In the practical sense, Stampar agreed with the views of progressive Chinese physicians such as R. Lim from the Peking Union Medical College, C.C. Chen from Ting Hsien and others, who believed that rationalization could reduce costs. For instance, education at nursing colleges could be merged with the university; the duration of medical school training could be cut to 4 years while making sure secondary school students receive better education in natural sciences. Štampar also supported medical education that would provide students with an insight into socio-economic problems that affected health, and include field training in rural areas. The role of the

Štampar A. Izabrani članci. Zagreb, Izdanja Škole narodnog zdravlja, JAZU; 1966, 51.

Ž. Dugac, M. Pećina (ed.) Andrija Štampar, Dnevnik s putovanja 1931-1938. Zagreb, HAZU, Srednja Europa, ŠNZ “Andrija Štampar”, 2008, 255. 
Peking Union Medical College as the best equipped medical school, the level of which was not attained by any other medical school in Far East, was to train teachers for all other medical schools, extant or in preparation. Štampar also suggested a method tested by the School of Public Health in Zagreb: organizing courses for licenced physicians to train them specifically to solve problems they were likely to encounter frequently in their work. These courses were to be organized by the health administration in Nanjing. Along with physicians, Štampar paid much attention to the education of nurses, which he saw equally important to the education of physicians. In this period in China, wrote Štampar, medical personnel were mostly educated at missionary hospitals. Štampar demanded the same standards for all of these schools. He also stressed that nurses and midwives should be able to perform same duties. ${ }^{78}$

\section{SHADOW OF THE WAR - CONCLUSION}

As the I930s approached their end, the political scene grew increasingly turbulent and brought unrest to public health projects. The mood that came to occupy the LNHO and RF staff was described in the following quote from Štampar's: "We (presumably Štampar and Borčić) talked to Gunn for long time; our conversation turned intimate when others left us, as we could not discuss everything openly in their presence; Gunn was once again depressed; the constant changes in this country, the uncertanties were taking their toll. His mood changed every day in response to the news; he wanted to do something good and permanent in China, he had put great efforts in this direction in New York and now he was worried that he would not be able to do it because of the most recent events. I consoled him by telling him about the positive sides of our stay; our moods improved when we relived memories from our trip through Yugoslavia I2 years ago. He remembered everything, which was a good indication of how much he had enjoyed that journey. He showed me his photographs taken in Dalmatia prominently displayed; he remembered all the details and asked about the people he had met there. He enjoyed talking about past times, about memories of his successful work in Europe. These memories soothed him in these difficult and uncertain times; I could observe on him a certain type of fatigue so frequently found in people disappointed with the present.

78 Štampar Andrija, Zdravstvene i socijalne prilike u Kini, Liječnički vjesnik, 59, 1937, 323 327. (Published in English in the Bulletin of the Health Organisation of the League of Nations, 5/1936, 1090-1126). 
He belongs to those people whose best days had happened ten years ago, when the future seemed so rosy; few could foresee events that happened afterwards." 79

By the end of the 1930s, the LNHO lost its position and authorities. ${ }^{80}$ Optimism waned and the League gradually withdrew all of its experts from the country. After Štampar, Berislav Borčić too left China, in 1938. The actual Chang Kai-shek government was sinking. Although the new public health projects shook the country and animated the people, and although Štampar's diplomacy was successful in obtaining funds to establish institutions and programmes, politics and war could not be fought. When analysing Andrija Štampar's diary, reports he sent to the LNHO, letters and reviews, about the enthusiasm of Chinese doctors, and the huge population that desperately needed health care, we gain the impression that the project of modernization and 'Westernization' of the Chinese public health launched by the LNHO in cooperation with the Chinese government had a good chance and strong local support. Yet the enthusiasm, new ideas, new projects encountered problems that intensified resistance caused by the political instability and lack of finances. Although, new institutions had a good chance to survive and develop, the political situation in the country threatened. The times did not allow the programme to survive; the political and ideological disunity of China was too large, the Japanese invasion too close. Many projects were launched, many were planned, yet in the dawn of the Second World War, everything that had been built through the I93os began to crumble. In the dawn of the Second World War, Štampar and Borčić left China, yet they could not avoid the war: it awaited them in Europe. As the threat of the armed conflict loomed, public health projects were all abandoned.

79 Ž. Dugac, M. Pećina (ed.) Andrija Štampar, Dnevnik s putovanja 1931-1938. Zagreb, HAZU, Srednja Europa, ŠNZ «Andrija Štampar», 2008, 491-492.

80 The last international conference before the war took place in Geneva in 1938 and it focused on the standardization of hormones. At the end of the war, in 1944, an international conference on the standardization of penicillin took place in London (Conferences of the League of Nations Health Organisation, LNHA, Geneva). After the Second World War, in changed social-political circumstances, the work of the LNHO was inherited first by the Intermittent Commission (1945-1948), and then the World Health Organisation (WHO). Both Andrija Štampar and Berislav Borčić gave significant contribution to the work of these institutions. See: Belicza B, Rastija M. Prilog poznavanju života i rada dra Berislava Borčića (1891-1977), eksperta Lige Naroda i Svjetske zdravstvene organizacije. Saopćenja 30, 1984, 129-144.; Dugac Ž, Fatović-Ferenčić S, Kovačić L, Kovačević T. Care for Health Cannot Be Limited to One Country or One Town Only, It Must Extend to Entire World: Role of Andrija Štampar in Building the World Health Organization, Croatian Medical Journal 49, 2008, 697-708. As the president of the Intermittent Commission, Štampar established the foundations for the Constitution of the WHO and thus steered the activities of the WHO in subsequent decades. He did this using the same principles he implemented in his work in the Kingdom of Yugoslavia in the 1920s and in China in the 1930s. 
The end of the Second World War brought profound changes in China. The old regime was replaced by the new, communist one. Yugoslavia too saw the end of the war profoundly changed. Here communist ideology assumed leadership as well. But while Tito's regime broke connections with USSR, China chose to stay near USSR. Štampar and Borčić never returned to China to work on public health. An indirect connection was maintained through the work of their disciple, Dr C. C. Chen, who remained active in the new circumstances. Yet the postwar world brought new exchanges of knowledge and experiences, from Croatia and Yugoslavia to the countries that came together in the Non-alignment movement. It is, however, without doubt that it was the interwar period and the Chinese experience made a contribution.

\section{Archival sources AND DOCUMENTS}

1. Annual Report of the Health Organisation for 1930, A.7.1931.III, April 1931, p.60, 62, LNHO Archives, Geneva.

2. Annual Report of the Health Organisation for 1930, p. 22. Archives of the LNHO, Geneva.

3. Annual report of the Health Organisation for 1930, p. 22. Archives of the LNHO, Geneva.

4. Annual report of the Health Organisation for 1930, pp. 60-63. Archive of the LNHO, Geneva.

5. European Conference on Rural Hygiene 1931, Minutes, LNHO Archives.

6. Health General, 8A/20164/3073, LNHO Archives, Geneva.

7. Health General, 8A/20827/3073, LNHO Archives, Geneva.

8. League of Nations, Minutes of the $96^{\text {th }}$ Sitting of the Council, 25 January 1937, LNHO Archive. Geneva.

9. Letter, Rajchman to McCoy, 7.12.1923, R852/28416/26189, LNHO Archives, Geneva.

10. Letter, Borčić to Rajchamn, 22.4.1924, R852/28416/26189, LNHO Archives, Geneva.

11. Letter, LNHO to B.Borčić, 21.5.1924, R852/28416/26189, LNHO Archives, Geneva.

12. Letter, B. Borčić to L. Rajchman, 21.8.1924, R852/28416/26189, LNHO Archives, Geneva.

13. Letter Borčić to Rajchamn, 21.9.1926, R928/51579/34384, LNHO Archives, Geneva. 
14. Letter B. Borčić to Norman White, 9.9.1927, R952/57565/41197, LNHO Archives, Geneva.

15. Letter Rajchman to Borčić, 26.6.1928, R928/51579/34384, LNHO Archives, Geneva.

16. Letter Štampar to Boudreau, 24.10.1930, 8B/18878/1218, LNHO Archives, Geneva.

17. Letter, Štampar to Rajchman, 28.5.1931, 8B/18878/1218, LNHO Archives, Geneva.

18. Letter Kuhn to Stampar, 1.11.1937, Personal fund A. Štampar HR HDA 831, Hrvatski državni arhiv, Zagreb.

19. Minutes of the Seventeenth Session of the Health Committee, 4-8.5.1931, Annex 7, Note by the Medical Director on the Report on Medical Schools in China, prepared by Professor Knud Faber, Archives of the LNHO, Geneva.

20. Provisional Program of Conference and Tour, 1.8.1927, R952/57565/41197, LNHO Archives, Geneva.

21. Telegram, Borčić to Štampar, 8.12.1931. Correspondence, Personal fund A. Štampar HR HDA 831, Hrvatski državni arhiv (Croatian State Archive), Zagreb.

\section{LITERATURE}

1. AnElissa L. Chinese Medical Modernization: Comparative policy continuities, 1930s-1980s, New York, Praeger, 1982.

2. Belicza B, Rastija M. Prilog poznavanju života i rada dra Berislava Borčića (18911977), eksperta Lige Naroda i Svjetske zdravstvene organizacije. Saopćenja 30, 1984, 129-144.

3. Borowy I, Gruner W. (eds.). Facing Illnesses in Troubled Times: Health in Europe in the Interwar Years. Frankfurt am Main: Peter Lang; 2005.

4. Borowy I. (ed.), Uneasy Encounters: The Politics of Medicine and Health in China 1900-1937, Frankfurt am Main, Peter Lang, 2009.

5. Borowy I. Coming to Terms with World Health: The League of Nations Health Organisation 1921-1946, Frankfurt am Main, Peter Lang, 2009.

6. Borowy I. Thinking Big - League of Nations Efforts towards a Reformed National Health System in China. In: Borowy I. (ed.), Uneasy Encounters: The Politics of Medicine and Health in China 1900-1937, Frankfurt am Main, Peter Lang, 2009, 205-228.

7. Brown Bullock, M., An American transplant, The Rockefeller Foundation and Peking Union Medical College, University of California Press, Berkeley, 1989.

8. Chen C.C. Medicine in Rural China. Berkley: University of California Press, 1989.

9. Dubin M. D. The League of Nations Health Organisation, in: Weindling P (eds.) International organisations and movements 1918-1939, Cambridge, Cambridge University Press, 1995. 
10. Dugac Ž, Fatović-Ferenčić S, Kovačić L, Kovačević T. Care for Health Cannot Be Limited to One Country or One Town Only, It Must Extend to Entire World: Role of Andrija Štampar in Building the World Health Organization, Croatian Medical Journal 49, 2008, 697-708.

11. Dugac Ž, Pećina M. (eds.) Andrija Štampar: dnevnik s putovanja 1931-1938, Zagreb, HAZU, Srednja Europa - ŠNZ Andrija Štampar, 2008.

12. Dugac Ž, Svijet kao domovina: Andrija Štampar i njegova međunarodna aktivnost tridesetih godina XX. Stoljeća, In Dugac Ž, Pećina M. (eds.) Andrija Štampar: Dnevnik s putovanja 1931-1938, Zagreb, HAZU, Srednja Europa, ŠNZ Andrija Štampar, 2008, XV-LVIII).

13. Dugac Ž. Andrija Štampar (1888-1958): Resolute Fighter for Health and Social Justice. In: Borowy I., Hardy A. (ed.), Of Medicine and Men: Biographies and Ideas in European Social Medicine between the World Wars, Frankfurt am Main, Peter Lang, 2008.

14. Dugac Ž. Like yeast in fermentation: public health in interwar Yugoslavia, In: Promitzer C., Trubeta S., Turda M. (eds.), Hygiene, Health and Eugenics in Southeastern Europe to 1945, Budapest, New York, CEU Press, 2010, 193-232.

15. Dugac Ž. New public health for a new state: interwar public health in the Kingdom of Serbs, Croats and Slovenes (Kingdom of Yugoslavia) and the Rockefeller Foundation. In: Borowy I., Gruner W. (eds.). Facing Illnesses in Troubled Times: Health in Europe in the Interwar Years, Frankfurt am Main, Peter Lang, 2005, pp. 277-304.

16. Dugac Ž. Protiv bolesti i neznanja: Rockefellerova fondacija u međuratnoj Jugoslaviji, Zagreb, Srednja Europa, 2005.

17. Dugac Ž., Kako biti čist $i$ zdrav: zdravstveno prosvjećivanje u međuratnoj Hrvatskoj, Zagreb, Srednja Europa, 2010.

18. Farley J. To Cast out Disease. A History of the International Health Division of the Rockefeller Foundation (1913-1951). Oxford, New York: Oxford University Press; 2004.

19. Goodman N. M., International Health Organizations and Their Work, Edinburgh, Churchill Livingstone, 1971.

20. Grmek M. D. U borbi za narodno zdravlje, Izabrani članci Andrije Štampara, Zagreb, ŠNZ Andrija Štampar, 1966.

21. Gross Solomon S, Murard L, Zylberman P. Shifting Boundaries of Public Health: Europe in the Twentieth Century. New York: University of Rochester Press; 2008.

22. Hiller S.M, Jewell J.A. Health Care and Traditional Medicine in China 1800-1982, London, Routledge, 1983.

23. Howard Jones N. International Public Health between the Two World Wars: The Organizational Problems, Geneve, World Health Organisation, 1978. 
24. Litsios S. Selskar Gunn and China: The Rockefeller Foundation's 'Other' Approach to Public Health, Bulletin of the History of Medicine, 79: 295-318, 2005.

25. Litsios S. The Rockefeller Foundation's Struggle to Correlate Its Existing Medical Program with Public Health Work in China; In: Borowy I. (ed.), Uneasy Encounters: The Politics of Medicine and Health in China 1900-1937, Frankfurt am Main, Peter Lang, 2009, 177-203.

26. Milovanović V. (ed). Medicinski godišnjak Kraljevine Jugoslavije. Beograd, Jugoreklam, 66 .

27. Prausnitz C. The Theaching of Preventive Medicine in Europe. London: Oxford University Press; 1933, 121-40, 169.

28. Štampar A. Izabrani članci. Zagreb, Izdanja Škole narodnog zdravlja, JAZU; 1966, 51.

29. Štampar Andrija, Zdravstvene i socijalne prilike u Kini, Liječnički vjesnik, 59, 1937, 323-327, a translation of a report in English originally published in the Bulletin of the Health Organisation of the League of Nations, 5/1936, 1090-1126.

30. Weindling P, ur. International organisations and movements 1918-1939. Cambridge: Cambridge University Press; 1995.

31. Weindling P. Philanthropy and World Healh: The Rockefeller Foundation and the League of Nations Health Organisation. Minerva 1997.

32. Yip K. Health and National Reconstruction in Nationalist China, Michigan, Association for Asian Studies, 1995.

\section{SAŽETAK}

Da bi se stekla kontrola i prevlast na određenom području, medicina je često služila kao alat $z$ a promicanje različitih interesa. Tragom aktivnosti $Z$ dravstvene organizacije Lige naroda $i$ Rockefellerove fondacije na području Kine 1930-ih, ovaj rad analizira međusobno povezivanje međunarodnih $i$ mjesnih čimbenika u preobrazbi tradicionalne kineske sredine u skladu $s$ novim i trendovskim projektima javnog zdravstva. Te su aktivnosti provedene ne samo radi poboljšanja uvjeta javnog zdravstva u zemlji već $i$ zbog uvođenja kineskoga javnog zdravstva $u$ proces internacionalizacije i standardizacije prema zapadno orijentiranom tipu medicine i medicinskog obrazovanja. Politički utjecaji, gospodarski interesi i kulturno okruženje, kao $i$ vojne akcije u ovom vrlo burnom razdoblju kineske povijesti nužno su djelovali na započete procese. Djelatnosti javnog zdravstva provodila je skupina međunarodnih stručnjaka. Među njima glavnu su ulogu imala dva hrvatska liječnika: Andrija Štampar (poslije jedan od osnivača Svjetske zdravstvene organizacije) i Berislav Borčić (ravnatelj Škole javnog zdravstva u Zagrebu). Na temelju korespondencije izmedu ta dva liječnika, kao i putopisnog dnevnika Andrije Štampara, ovaj esej prikazuje neke manje poznate pojedinosti o stanju u Kini i medusobnom isprepletanju politike i medicine.

Ključne riječi: povijest javnog zdravstva, povijest medicine, Kina između dva svjetska rata, Andrija Štampar, Berislav Borčić 